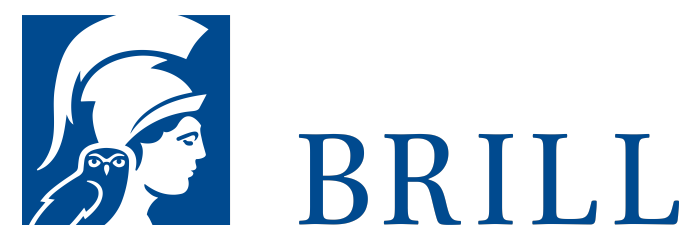

\title{
Die Konzilien in Lateinamerika
}

Teil II: Lima 1551-1927

Authors: Willi Henkel OMI and Josep-Ignasi Saranyana

Die lateinamerikanischen Konzilien können in ihrer Bedeutung für die jungen Kirchenprovinzen nicht überschätzt werden. Die Provinzialkonzilien von Lima dokumentieren das Werden und Wachsen der Kirchenprovinz. Das bedeutendste von ihnen, das III. Konzil 1582-1583, verwirklicht das Konzil von Trient. Glanzleistungen des Konzils waren der Katechismus, das Predigtbuch und das Beichtbuch, die 1584 als erste Bücher in Lima auf Spanisch, Quetchua und Aymara erschienen einmalige historische Dokumente, die bis ins 20. Jahrhundert im Gebrauch waren.

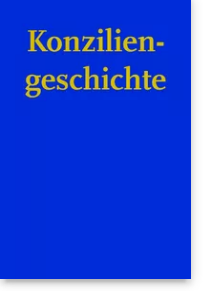

Pages: XXVI + 306 Seiten

Language:

German

Subjects:

General,

Theology and

World

Christianity

Publisher: Brill |

Schöningh

Series:

Konziliengeschichte

- Reihe A:

Darstellungen

E-Book (PDF)

Released online:

15 Jul 2019

ISBN: 978-3-

657-72865-7

List price

USD $\$ 75.00$

Hardback

Publication date:

17 Mar 2010

ISBN: 978-3-

506-72865-4

List price

USD $\$ 75.00$ 
For more information see brill.com

Order information: Order online at brill.com +44330 333 0049 | customerservices@brill.com Submission information: brill.com/authors

Titles published by Brill | Fink, Brill | mentis or Brill | Schöningh: +49(o)715413279216| brill@brocom.de 